\title{
PENGGUNAAN MODEL PEMBELAJARAN WORD SQUARE UNTUK MENINGKATKAN HASIL BELAJAR SISWA PADA PELAJARAN PENDIDIKAN KEWARGANEGARAAN DI KELAS V SD NEGERI 054938 KAB. LANGKAT
}

\author{
Numayani \\ Surel: nurmayani@gmail.com
}

\begin{abstract}
This study aims to determine the improvement of student learning outcomes by using the model of learning Word Square padapelajaran civic education in VSD class 054938 academic year 2017 / 2018. The problem in this study is the result of student's civic education learning is low on the material freedom of organization in class V SD Negeri 054938 Pangkalan Dress up academic year 2017/2018. This type of research is classroom action research conducted with 2 cycles and 4 stages namely, planning, implementation, observation, and reflection. With the subjects of research are 24 students of grade V SD Negeri 054938 with rician 12 men and 12 women. The data collection tool is a test of learning outcomes and observation sheets.
\end{abstract}

Keywords: Word Square, Student Learning Outcomes, Citizenship Education.

\begin{abstract}
ABSTRAK
Penelitian ini bertujuan untuk mengetahui peningkatan hasil belajar siswa dengan menggunakan model pembelajaran Word Square padapelajaran pendidikan kewarganegaraan di kelas V SD Negeri 054938 tahun ajaran 2017/2018. Masalah dalam penelitian ini adalah hasil belajar pendidikan kewarganegaraan siswa rendah pada materi kebebasan berorganisasi di kelas V SD Negeri 054938 Pangkalan Berandan tahun ajaran 2017/2018. Jenis penelitian ini adalah penelitian tindakan kelas (classroom action research) yang dilaksanakan dengan 2 siklus dan 4 tahapan yaitu, perencanaan, pelaksanaan, pengamatan, dan refleksi. Dengan subjek penelitian yaitu 24 siswa kelas V SD Negeri 054938 dengan rician 12 lakilaki dan 12 perempuan. Adapun alat pengumpulan datanya adalah tes hasil belajar dan lembar observasi.
\end{abstract}

Kata Kunci: Word Square, Hasil Belajar Siswa, Pendidikan Kewarganegaraan.

\section{PENDAHULUAN}

Guru dan pendidikan merupakan dua aspek yang saling berkitan. Dalam arti luas pendidikan meliputi semua perbuatan dan usaha dari generasi tua untuk mengalihkan pengetahuan, pengalaman, kecakapan, dan keterampilannya kepada generasi muda sebagai usaha menyiapkannya agar dapat memenuhi fungsi hidupnya baik jasmaniah maupun rohaniah. Artinya pendidikan adalah usaha secara sengaja dari orang dewasa untuk meningkatkan kedewasaan yang selalu diartikan dengan pengaruhnya mampu menimbulkan tanggung jawab moril dari segala perbuatannya (Sagala, 2011:3).

Orang dewasa yang dimaksud dalam hal ini adalah guru. Guru merupakan fasilitator utama dalam dunia pendidikan. Guru berperan penting dalam kelas untuk 
mengontrol dan mengarahkan kegiatan belajar ke arah tercapainya tujuan yang telah di rumuskan. Tingkat keberhasilan guru dalam mengajar dilihat dari keberhasilan peserta didiknya. Kualitas pembelajaran dilihat dari aktivitas peserta didik ketika belajar dan kreativitas guru dalam mengembangkan pembelajaran. Guru disamping harus menguasai bahan ajar atau materi ajar, tentu perlu pula mengetahui bagaimana cara agar materi ajar itu disampaikan. Guru juga harus memahami bagaimana karakteristik peserta didik yang menerima materi pelajaran tersebut. Guru memiliki tugas memilih strategi, pendekatan, metode, ataupun model yang sesuai denga materi dan tujuan pembelajaran yang ingin di sampaikan. Memilih suatu model pembelajaran harus memiliki pertimbangan-pertimbangan.

Misalnya, materi pelajaran, tingkat perkembangan kognitif siswa, dan sarana atau fasilitas yang tersedia. Hal yang sangat penting bagi para pengajar untuk mempelajari dan menambah wawasan tentang model pembelajaran yang telah diketahui. Karena dengan menguasai beberapa model pembelajaran, maka seorang guru akan merasakan adanya kemudahan dalam pembelajaran. Namun beradasarkan hasil observasi di SD 054938, guru dalam memberikan pelajaran masih menggunakan metode konvensional yaitu metode ceramah sehingga anak didik merasa jenuh dan bosan saat menerima pelajaran yang telah diberikan oleh guru khusunya pada pelajaran pendidikan kewarganegaraan.

Pendidikan kewarganegaraan merupakan salah satu pelajaran di SD. Pada Kurikulum Tingkat Satuan Pendidikan (KTSP), tujuan yang ingin dicapai melalui pembelajaran pendidikan kewarganegaraan di SD adalah untuk menjadikan siswa: (1) mampu berpikir secara kritis, rasional, dan kreatif dalam menanggapi persoalan hidup maupun isu kewarganegaraandi negaranya, (2) mau berpartisipasi dalam segala bidang kegiatan, secara aktif dan bertanggung jawab, sehingga bisa bertindak secara cerdas dalam semua kegiatan, (3) bias berkembang secara positif dan demokratis, maka guru sebagai ujung tombak dalam pelaksanaan pendidikan merupakan pihak yang sangat berpengaruh dalam prosesbelajar mengajar.

Dari hasil wawancara dengan guru kelas $\mathrm{V}$ pada pelajaran pendidikan kewarganegaraan diperoleh informasi bahwa dari KKM yang sudah ditetapkan masih ada sekitar $54,2 \%$ anak yang belum memenuhi KKM, atau hanya sekitar 11 orang anak dengan persentase $45,8 \%$ yang sudah memperoleh nilai setara atau diatas KKM. Hal tersebut menunjukkan bahwa hasil belajar siswa pada mata pelajaran pendidikan kewarganegaraan masih rendah. Maka dari itu, peneliti tertarik menggunakan model pembelajaran word square karena 
model word square dapat membuat peserta didik terlibat aktif dalam kompetisi sehingga dapat membuat peserta didik bersemangat dalam proses pembelajaran, mampuberpikir secara kritis, rasional, dan kreatif dan mengajarkan tanggung jawab kepada peserta didik untuk melakukan yang terbaik bagi kelompok mereka.

Selain itu, model word square dapat melatih keterampilan membaca dan ketelitian peserta didik, karena dalam metode ini peserta didik dituntut untuk mencari jawaban atau kata yang berkaitan dengan soal yang diberikan oleh guru kemudian peserta didik mencari kata dari beberapa huruf pengecoh dari kotak yang ada. Maka dari itu, guru harus mampu memprogram sejumlah pertanyaan terpilih yang dapat merangsang siswa untuk berpikir efektif. Siswa harus memahami materi pelajaran yang disampaikan guru selama proses pembelajaran, karena model pembelajaran word square memerlukan pengetahuan dasar dari siswa. Sehingga pada akhirnya siswa mampu mengerjakanan LKS dalam bentuk word square. Model pembelajaran word square juga dapat menumbuhkan partisipasi siswa, rasa tanggung jawab, sikap kritis, teliti serta kreativitas dalam belajardan pada akhirnya meningkatkan hasil belajar siswa.

Belajar adalah usaha pendewasaan siswa yang dilakukan dengan membekali siswa dengan berbagai ilmu pengetahuan, keterampilan, sehingga dengan pengetahuan dan keterampilan tersebut siswa dapat sukses menjalani kehidupannya, baik pada masa sekarang maupun pada masa yang akan datang. Melalui belajar siswa dapat memahami dan mengetahui apa yang belum diketahui. Agar pengetahuan dapat dipahami siswa dengan baik, maka perlu diperhatikan model yang digunakan guru dalam mengajar, yang mendukung efektifnya proses belajar mengajar.

Proses pembelajaran yang baik yang pada gilirannya dapat mencapai hasil belajar yang optimal. Cara guna dalam menyampaikan materi pelajaran yang menempati posisi yang sangat penting yang turut menentukan tercapainya hasil belajar yang optimal. Dengan menggunakan metode pembelajaran konvesional biasa, siswa sering kali merasa bosan dan hal itulah yang terjadi dalam proses pembelajaran pendidikan kewarganegraan di SD. Siswa kurang tertarik dengan pelajaran yang disampaikan sehingga tidak memahami materi yang disampaikan dan akibatnya berimbas pada rendahnya hasil belajar siswa.

$$
\text { Hasil belajar seringkali }
$$
digunakan sebagai ukuran untuk mengetahui seberapa jauh seseorang menguasai bahan yang sudah diajarkan. Hasil belajar adalah suatu pernyataan yang spesifik yang dinyatakan dalam perilaku dan penampilan yang diwujudkan dalam bentuk tulisan untuk menggambarkan hasil belajar yang diharapkan. 
Untuk mengatasi rendahnya hasil belajar siswa, maka perlu dilakukan evaluasi terhadap proses pembelajran. Memperhatikan model pembelajran yang digunakan guru dan bagaimana dampaknya terhadap perkembangan hasil belajar siswa. Suasana belajar dan hal lain juga tak luput dari perhatian. Dalam hal ini yang dianggap dapat mengatasi rendahnya hasil belajar tersebut adalah pemilihan model pembelajaran yang tepat. Maka dari itu dipilihlah model pembelajran word square sebagai alteratif model peningkatan hasil belajar siswa.

Model Pembelajaran word square merupakan salah satu model pembelajar yang dapat digunakan guru unruk mencapai tujuan pembelajaran. Model ini secara teknis adalah kegiatan belajar mengajar dengan cara guru membagikan lembar kegiatan atau lembar kerja sebagai alat untuk mengukur tingkat pemahaman siswa terhadap materi pelajaran yang telah diajarkan.

Model ini juga merupakan model yang memadukan kemampuan menjawab pertanyaan dengan kejelian dalam mencocokkan jawaban pada kotak-kotak jawaban. Kotak-kotak yang telah dipersiapkan akan diisi oleh siswa dengan cara mengarsir huruf-huruf yang ada yang mrupakan jawaban dari pertanyaan yang dipersiapkan oleh guru. Model ini sedikit lebih mirip dengan mengisi teka-teki silang, akan tetapi perbedaan yang mendasar adalah model ini sudah memiliki jawaban, namun disamarkan dengan menambahkan kotak tambahan dengan sembarang huruf atau angka penyamar atau pengecoh. Istimewanya model ini adalah bisa dipraktekkan untuk semua mata pelajaran, hanya tinggal bagaimana guru dapat memprogram sejumlah pertanyan terpilih yang dapat merangsang siswa untuk berpikir efektif.

\section{METODE PENELITIAN}

Jenis penelitian ini digolongkan pada penelitian tindakan (action research). Dalam hal ini, karena subyek yang hendak diteliti adalah sekelompok siswa didalam kelas, maka jenis penelitian yang digunakan yaitu penelitian tindakan kelas (classroomaction research).

Menurut Dewi (2015:10), "mengatakan penelitian tindakan kelas didefinisikan sebagai suatu bentuk penelitian yang bersifat reflektif dengan melakukan tindakantindakan tertentu agar memperbaiki dan meningkatkan praktek-praktek pembelajaran dikelas secara lebih professional."

Selain itu, menurut Wardani, dkk (2006:4), “mengatakan penelitian tindakan kelas adalah penelitian yang dilakukan oleh guru didalam kelasnya sendiri melalui refleksi diri, dengan tujuan untuk memperbaiki kinerjanya sebagai guru, sehingga hasil belajar siswa menjadi meningkat (lebih baik)".

Penelitian direncakan akan dilaksanakan di SD Negeri 054938 Jalan Piturah Paya Glugur 
Kecamatan Sei Lepan Kabupaten langkat. Waktu penelitian direncakan dilaksanakan pada awal semester genap tahun ajaran 2017/2018 dalam rentang waktu selama 2 (dua) bulan, dimulai dari bulan Januari hingga Maret 2017.

Subjek pada penelitian ini adalah siswa-siswa kelas $\mathrm{V}$ SD Negeri 054938 tahun pelajaran 2017/2018 yang berjumlah 24 orang, dengan rician 12 laki-laki dan 12 perempuan. Rata- rata usia siswa yang menjadi subjek pada penelitian ini adalah antara 11-12 tahun.

Objek pada penelitian ini adalah kemampuan siswa dalam memahami pelajaran pendidikan kewarganegaraan materi kebebasan berorganisasi dengan menggunakan model pembelajaran word square.

Secara garis besar terdapat tahapan yang akan dilalui dalam penelitian tindakan kelas yaitu: (1) perencanaan, (2) pelaksanaan, (3) pengamatan, dan (4) refleksi. Penelitian ini akandilaksanakan di kelas V SD Negeri 054938. Penelitian ini direncanakan dilakukan pada bulan Januari-Maret 2017.

\section{HASIL PENELITIAN DAN PEMBAHASAN}

Penelitian ini dilaksanakan di SD Negeri 054938 Paya Glugur Kelurahan Alur Dua Kecamatan Sei Lepan di kelas V (lima). Siswa kelas $\mathrm{V}$ (lima) terbagi dalam 2 (dua) kelas yaitu kelas V (lima) A dan kelas V (lima) B. Penelitian dilakukan disalah satu kelas yaitu kelas V (lima) B. Jumlah siswa kelas V (lima) B adalah 24 orang, terdiri dari 12 laki - laki dan 12 perempuan. Sarana dan prasarana yang ada di dalam kelas terdiri dari papan tulis, papan absen, lemari, spidol dan penghapus, dispenser dan air aqua galon, meja dan kursi guru, meja siswa terdiri dari 16meja dan kursi siswa sebanyak 32 kursi.

Pelaksanan penelitian dilaksanakan sesuai dengan waktu yang sudah ditetapkan berdasarkan hasil diskusi antara peneliti dan mitra kolaborasi (guru kelas) pada tanggal 19 Januari 2018. Penelitian ini dilengkapi dengan lembar observasi yang bertujuan untuk mengamati perilaku siswa saat pembelajaran berlangsung. Pembelajarandisajikan dengan menerapkan model pembelajara word square untuk meningkatkan hasil belajar siswa kelas V (lima) B semester genap Tahun Pelajaran 2017/2018. Penelitian ini dilakukan sebanyak dua siklus.

Berdasarkan hasil diskusi antara peniliti dan guru pada tanggal 19 Januari, maka ditetapkalah tanggal 23 Januari 2018 untuk diadakannya tes awal (Pretest) bagi siswa. Pemberian pretest ini bertujuan untuk mengetahui kondisi awal siswa sebelum diberi perlakuan. Pemberian pretest juga bertujuan untuk mengetahui kesulitankesulitan yang dialami siswa pada saat menerima pelajaran dari guru, sehingga peneliti nantinya dapat meminimalisir masalah yang dialami siswa. Pada hari Selasa, 23 Januari 
2018, sebelum siklus I dilaksanakan dan materi diajarkan para siswa yang berjumlah 24 orang, diberikanlah tes awal sebanyak 20 soal dalam bentuk pilihan berganda. Dari hasil yang diperoleh, hanya sebagian kecil siswa yang mampu menjawab semua soal dengan benar dengan jumlah skor nilai 1205. Ratarata yang diperoleh adalah 50,21 dengan persentase ketuntasan secara klasikal adalah $12,5 \%$ karena hanya ada 3 (tiga) orang siswa yang tuntas KKM $(\geq 75)$. Siswa yang tuntas pada pretest ini, ketiganya memperoleh nilai 75 yang menjadi KKM di sekolah tersebut untuk pelajaran pendidikan kewarganegaraan kelas $\mathrm{V}$.

Proses penelitian yang dilakukan oleh peneliti dengan menggunakan model pembelajaran word square dalam penelitian ini dilakukan sebanyak dua siklus dan masing-masing siklus dilakukan sebanyak dua kali pertemuan pada materi kebebasan berorganisasi di kelas V SD. Pelaksanaan tindakan dilakukan di SD 054938 tepatnya di ruang kelas $\mathrm{V}$ (lima B) dengan jumlah siswa yang mengikuti proses pembelajaran sebanyak 24 orang, dengan rincian 12 laki-laki dan 12 perempuan pada tahun ajaran 2017/2018. Peneliti dibantu oleh guru mata pelajaran pendidikan kewarganegaran kelas $\mathrm{V}$ selaku mitra kolaborasi yang bertindak dalam melakukan pengamatan tentang aktivitas siswa dan kegiatan peneliti dalam menerapkan RPP dengan model pembelajaran word square. Setelah semua materi diajarkan, pada akhir tiap siklus dilakukan evaluasi dengan memberikan seperangkat tes kepada siswa untuk mengetahui hasil belajar siswa setelah diberikan tindakan.

Penggunaan

model pembelajaran word square menunjukkan peningkatan rata-rata hasil belajar pendidikan kewarganegaraan dan persentase keberhasilan belajar siswa secara klasikal pada materi kebebasan berorganisasi. Peningkatan hasil belajar siswa pada kebebasan berorganisasi, mulai dari pretes, postes siklus I dan postes siklus II, secara ringkas dapat dilihat pada tabel 1 berikut:

Tabel 1. Peningkatan Hasil Belajar Berdasarkan Pretest, Postes I dan II

\begin{tabular}{c|c|c|c|c|c}
\hline No. & Nama Siswa & Pretest & Postes I & Postes II & Keterangan \\
\hline 1. & 01 & 75 & 85 & 95 & Meningkat \\
\hline 2. & 02 & 60 & 80 & 85 & Meningkat \\
\hline 3. & 03 & 70 & 85 & 90 & Meningkat \\
\hline 4. & 04 & 55 & 65 & 80 & Meningkat \\
\hline 5. & 05 & 75 & 85 & 90 & Meningkat \\
\hline 6. & 06 & 20 & 60 & 75 & Meningkat \\
\hline 7. & 07 & 50 & 60 & 75 & Meningkat \\
\hline
\end{tabular}


SCHOOL EDUCATION JOURNAL VOLUME 8 NO. 1 JUNI 2018

\begin{tabular}{c|c|c|c|c|c}
\hline 8. & 08 & 55 & 70 & 85 & Meningkat \\
\hline 9. & 09 & 55 & 70 & 75 & Meningkat \\
\hline 10. & 10 & 60 & 85 & 95 & Meningkat \\
\hline 11. & 11 & 45 & 70 & 85 & Meningkat \\
\hline 12. & 12 & 50 & 70 & 75 & Meningkat \\
\hline 13. & 13 & 30 & 55 & 70 & Meningkat \\
\hline 14. & 14 & 70 & 85 & 90 & Meningkat \\
\hline 15. & 15 & 45 & 75 & 85 & Meningkat \\
\hline 16. & 16 & 50 & 65 & 80 & Meningkat \\
\hline 17. & 17 & 55 & 75 & 85 & Meningkat \\
\hline 18. & 18 & 10 & 50 & 70 & Meningkat \\
\hline 19. & 19 & 60 & 75 & 85 & Meningkat \\
\hline 20. & 20 & 30 & 55 & 75 & Meningkat \\
\hline 21. & 21 & 45 & 65 & 80 & Meningkat \\
\hline 22. & 22 & 40 & 65 & 80 & Meningkat \\
\hline 23. & 23 & 25 & 60 & 75 & Meningkat \\
\hline 24 & 24 & 75 & 90 & 100 & Meningkat \\
\hline \multicolumn{2}{r|}{ Jumlah Nilai } & 1205 & 1700 & 1980 & \\
\hline \multicolumn{2}{r|}{ Rata-rata Nilai } & 50,21 & 70,83 & 82,50 & Meningkat \\
\hline \multicolumn{2}{|c|}{ Keberhasilan } & $12,50 \%$ & $41,67 \%$ & $91,67 \%$ & Tercapai \\
\hline
\end{tabular}

Berdasarkan tabel 1. di atas tampak bahwa rata-rata hasil belajar pendidkkan kearganegaraan siswa pada materi kebebasan berorganisasi di kelas $\mathrm{V}$ mengalami peningkatan mulai dari pretest, post test I hingga post test II. Sebelum dilakukan tindakan dari hasil pretest diperoleh nilai rata-rata kemampuan awal siswa tentang materi kebabasan berorganisasi sebesar 50,21. Setelah dilakukan siklus I, berdasarkan hasil post test I rata-rata hasil belajar pendidikan kewarganegaraan siswa mengalami peningkatan dengan ratarata 70,83. Selanjutnya setelah dilakukan perbaikan pembelajaran pada siklus II, berdasarkan hasil post test II diporel nilai rata-rata 82,50. Peningkatan rata-rata hasil belajar pendidikan kewarganegraan siswa dapat divisualisasikan pada grafik 1 . berikut: 


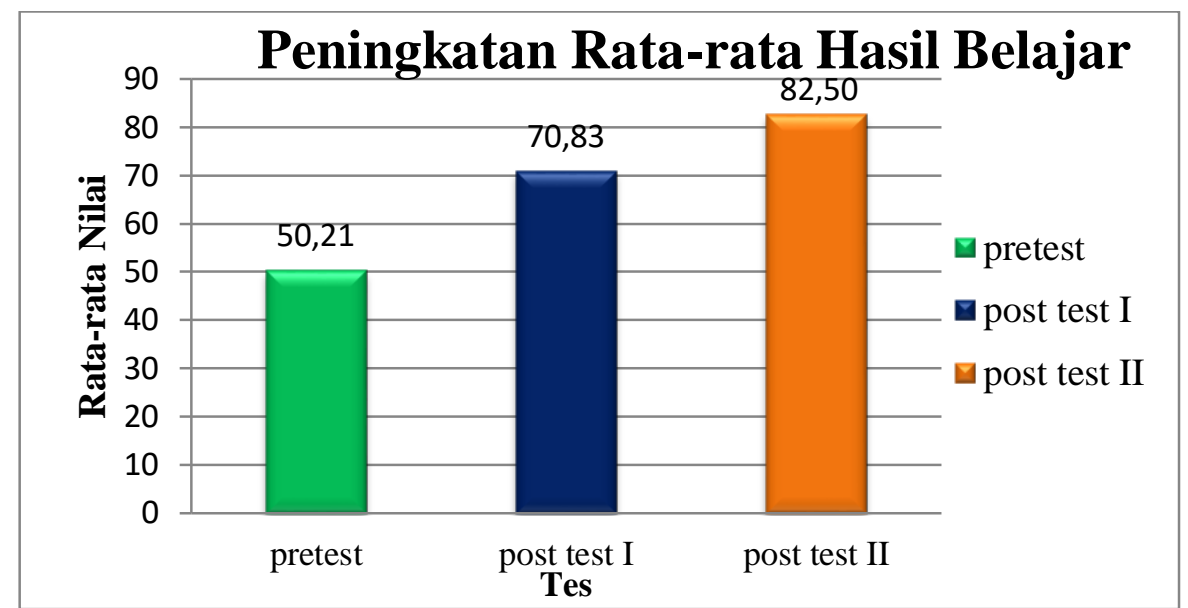

Gambar 3. Grafik Perbandingan Peningkatan Rata-rata Hasil Belajar Pendidikan Kewarganegaraan Siswa

Tabel 1. juga menunjukkan adanya peningkatan persentase keberhasilan belajar siswa secara klasikal mulai dari pretest, post test I hingga post test II. Dari hasil pretest tampak persentase keberhasilan siswa secara klasikal hanya $12,50 \%$ sedangkan dari hasil postes I diperoleh persentase keberhasilan klasikal meningkat menjadi 41,67\%. Selanjutnya dari hasil postes II persentase keberhasilan klasikal juga meningkat menjadi 91,67\%. Peningkatan keberhasilan belajar siswa secara klasikal dapat divisualisasikan pada grafik 4 . berikut ini:

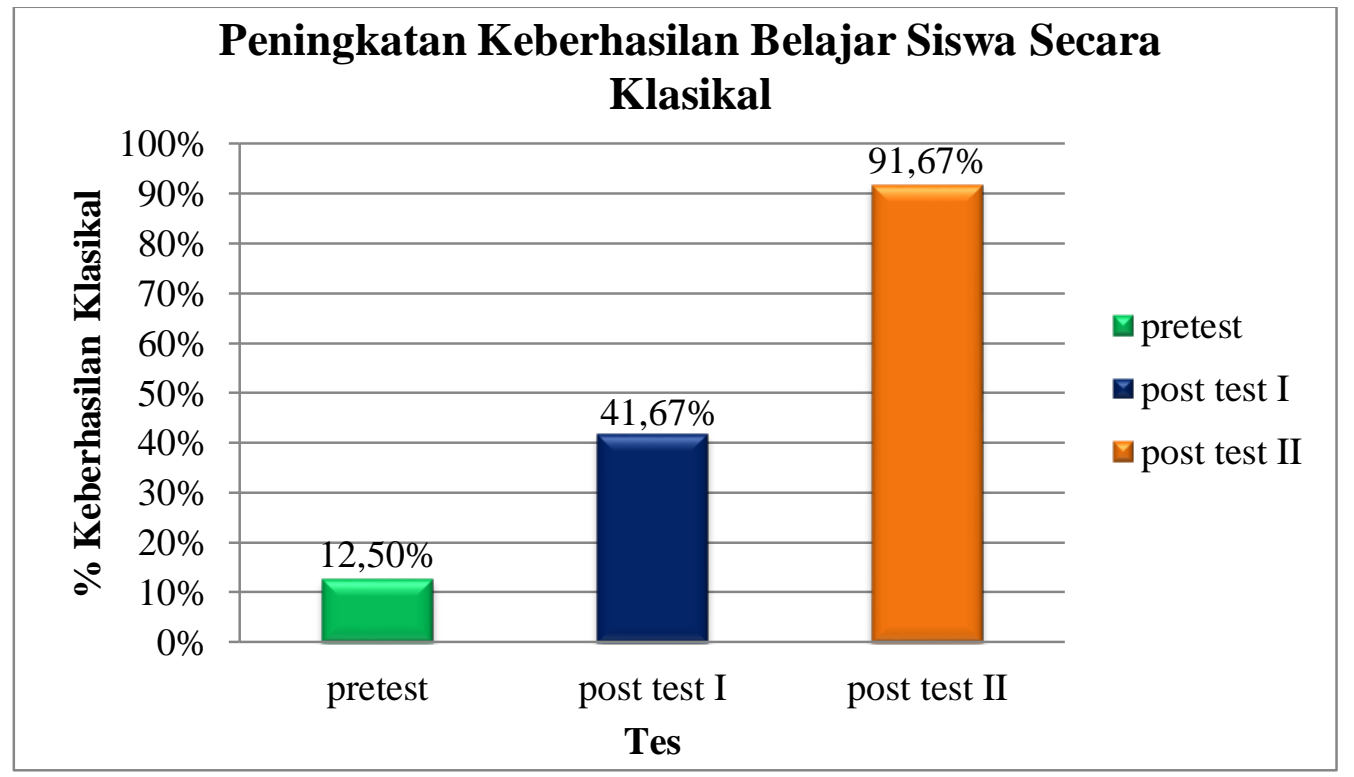

Gambar 4. Grafik Persentase Peningkatan Keberhasilan Belajar Siswa Secara Klasikal (Kelas)

Berdasarkan hasil-hasil temuan penelitian, menunjukkan bahwa rata- rata kemampuan awal siswa hanya sebesar 50,21 dengan keberhasilan 
siswa secara klasikal 12,50\%. Hal ini menunjukkan bahwa kemampuan awal dan keberhasilan siswa secara klasikal masih tergolong rendah sehingga perlu dilakukan tindakan siklus I. Pada siklus I, dilakukan pembelajaran dengan materi kebebasan berorganisasi menggunakan model pembelajaran word square. Pelaksanaan tindakan siklus I dilakukan selama 2 kali pertemuan, dan diakhir pembelajaran diberikan tes (post test I) dan diperoleh rata-rata hasil belajar sebesar 70,83 dengan persentase siswa yang berhasil secara klasikal sebesar $41,67 \%$. Dari data tersebut telihat peningkatan dari sebelum diberi tindakan dan setelah diberikan tindakan. Meskipun mengalami peningkatan, akan tetapi siswa yang telah berhasil dalam belajar yaitu hanya $41,67 \%$, dan secara klasikal siswa masih dinyatakan belum mencapai keberhasilan dalam belajar karena masih kurang dari $85 \%$ yang diharapkan.

Kurang maksimalnya hasil dan keberhasilan belajar yang dicapai siswa secara klasikal dikarenakan kurangnya keaktifan siswa dalam kegiatan pembelajaran atau rata-rata jumlah siswa yang aktif dalam kegiatan pembelajaran pada pertemuan pertama siklus I hanya $56,56 \%$ dan tergolong rendah, pertemuan kedua siklus I mengalami peningkatan menjadi $71,15 \%$ dan tergolong baik namun masih ada beberapa aspek yang perlu ditingkatkan. Dari hasil pengamatan mitra kolaborasi hingga pertemuan kedua siklus I, terlihat beberapa aspek yang masih kurang atau tergolong rendah yaitu siswa masih kurang memiliki keberanian dalam bertanya tentang hal-hal yang kurang dimengerti, masih kurang bertanggung jawab terhadap tugas yang diberikan, masih mengalami kesulitan dalam mencocokkan soal dengan jawaban, dan yang terakhir masih kurang lacar dalam menjawab pertanyaan dari peneliti.

Masih adanya beberapa aspek yang perlu ditingkatkan pada siklus I tentang aktivitas siswa menuntut peneliti untuk melakukan peningakatan pada siklus II ini. Pada siklus II ini, peneliti berusaha melibatkan siswa secara aktif dalam kegiatan pembelajaran dengan memotivasi siswa lebih berani atau tidak malu bertanya, lebih menertibkan keadaan kelas dan memberikan kesempatan bagi siswa untuk bertanya, dan membimbing siswa lebih teliti dalam memahami soal-soal. Sehingga pada pertemuan pertama siklus II keaktifan siswa rata-rata $81,67 \%$ dan sampai dengan peremuan kedua siklus II mencapai $84,90 \%$. Hal itu menunjukkan peningkatan dibandingkan siklus sebelumnya. Dari hasil postes siklus II diperoleh rata-rata hasil belajar pendidikan kewarganegaraan sebesar 82,50 dengan persentase keberhasilan secara klasikal sebesar 91,67\%. Berdasarkan rata-rata hasil belajar pendidikan kewarganegraan yang diperoleh siswa pada postes siklus II menunjukkan adanya peningkatan dibandingkan postes 
siklus I maupun sebelum diberikan tindakan (pretes) dan jumlah siswa yang telah berhasil dalam belajar sebesar 91,67\% sehingga secara klasikal dinyatakan bahwa para siswa telah mencapai keberhasilan dalam belajar yang diharapkan yaitu $85 \%$.

\section{Pembahasan}

Berdasarkan hasil penelitian yang telah dilakukan oleh peneliti serta pengamatan yang dilakukan oleh mitra kolaborasi yang dilakukan dari siklus I hingga siklus II, diperoleh data yang menunujukkan peningkatan hasil belajar siswa pada pelajaran pendidikan kewarganegraan. Peningkatan ini disebabkan karena penggunaan model pembelajaran word squaremampu meningkatkan semangat siswa dalam belajar dan menjadikan siswa lebih aktif dan kreatif, teliti dalam mengerjakan soal serta mampu memahami materi dengan baik.

Hasil penelitian ini sejalan dengan penelitian yang telah dilakukan oleh Luh Putu Sukandheni pada tahun 2014 dengan judul "Pengaruh Penerapan Model Pembelajaran Kooperatif Tipe Word Square Berbasis Lingkungan terhadap Hasil Belajar IPA Kelas V Gugus Budi Utomo Denpasar Timur". Hasil penelitiannya menunjukkan bahwa terdapat perbedaan yang signifikan hasil belajar IPA antara siswa yang dibelajarkan menggunakan model pembelajaran kooperatif tipe word square berbasis lingkungan dengan pembelajaran konvensional. Dilihat dari rata-rata nilai gain skor kelas eksperimen sebesar 0,82 dan ratarata nilai gain skor kelas kontrol sebesar 0,55. Perbandingan kategori hasil belajar IPA siswa kelas eksperimen yang menggunakan model pembelajaran kooperatif tipe word squareberbasis lingkungan berada pada kategori baik dengan presentase 46\%, kategori cukup dengan presentase 29\%, kategori kurang dengan presentase 20\%,dan kategori sangat kurang dengan presentase 5\% dan kategori hasil belajar IPA siswa kelas kontrol yang menggunakan pembelajaran konvensional berada pada kategori sangat baik dengan persentase $5 \%$, kategori baik dengan presentase 23\%, kategori cukup denganpresentase 44\%, kategori kurang dengan presentase $17 \%$, dan kategori sangat kurang dengan presentase $11 \%$. Dari perhitungan uji t diperoleh thitung sebesar 3,03 dan ttabelsebesar 2,00. Karena thitung > ttabel(3,03 >2,00). Maka hipotesis observasi (ho) ditolak dan hipotesis alternatif (ha) diterima, sehingga dapat diinterpretasikan bahwa, terdapat perbedaan yang signifikan hasil belajar IPA siswa yang dibelajarkan menggunakan Model Pembelajaran Kooperatif Tipe Word Square Berbasis Lingkungan dengan siswa yang dibelajarkan menggunakan pembelajaran konvensional pada siswa Kelas V Gugus Budi Utomo Denpasar Timur. Hal serupa juga dikemukakan oleh Yesi Ratnasari melalui 
penelitian yang dilakukan pada tahun 2014 dengan judul "Penerapan Model Pembelajaran Word Square untuk Meningkatkan Aktivitas dan Hasil Belajar Siswa Kelas V Mata Pelajaran PKn Pokok Bahasan Keputusan Bersama di SDN Umbulrejo 01 Jember Tahun Pelajaran 2013/2014". Hasil penelitiannya menunjukkan bahwa penerapan model pembelajaran word square dapat meningkatkan aktivitas dan hasil belajar. Hal ini terbukti skoraktivitas belajar siswa pada sebelum tindakan 51,1 (kategori cukup aktif) pada siklus I 77,5 (kategori aktif) sehingga pada siklus I mengalami peningkatan sebesar 26,4, dan pada siklus II 92,2 (kategori sangat aktif) sehingga pada siklus II mengalami peningkatan sebesar 14,7. Penerapan pembelajaran Word Square juga dapat meningkatkan hasil belajar siswa. Terbukti pada skor ratarata hasil belajar siswa secara klasikal pada prasiklus sebesar 67,6 dengan kategori cukup baik. Pada siklus I mengalami peningkatan sebesar 5,7 sehingga skor menjadi 73,3 dengan kategori baik. Pada siklus II juga mengalami peningkatan sebesar 8,1 sehingga skor rata-rata hasil belajar siswa secara klasikal sebesar 81,4 dengan kategori sangat baik.

Dengan demikian, merujuk pada beberapa penelitian sebelumnya terbukti bahwa model pembelajaran word square mampu meningkatkan hasil belajar siswa dan dapat disimpulkan bahwa model pembelajaran word square dapat meningkatkan hasil belajar siswa pada pelajaran pendidikan kewarganegaraan di kelas V (lima) dengan materi kebebasan berorganisasi SD Negeri 054938 Paya Glugur Kecamatan Sei Lepan Kabupaten Langkat tahun ajaran 2017/2018.

\section{SIMPULAN}

Berdasarkan hasil penelitian, analisis dan refleksi dari tiap-tiap siklus dapat disimpulkan bahwa penggunaan model pembelajaran word square dapat meningkatkan hasil belajar pendidkan kearganegaraan siswa pada materi kebebasan berorganisasi di kelas $\mathrm{V}$ (lima). Peningkatan hasil belajar siswa dapat dibuktikan dari rata-rata nilai dan keberhasilan belajar siswa secara klasikal berdasarkan hasil pretes, postes siklus I dan postes siklus II.

a. Dari penelitian yang dilakukan, sebelum diberikan tindakan dari hasil pretest diperoleh rata-rata kemampuan awal siswa sebesar 50,21 dengan persentase keberhasilan belajar secara klasikal yaitu $12,50 \%$ atau hanya 3 orang siswa yang meperoleh nilai tuntas. Setelah dilakukan tindakan siklus I dari hasil postes I diperoleh hasil belajar siswa meningkat menjadi ratarata 70,83 dengan persentase keberhasilan belajar secara klasikal yaitu 41,67\% atau hanya 10 orang siswa yang meperoleh nilai tuntas dan belum dapat dikatakan berhasil karena belum 
mencapai $85 \%$ yang menjadi taraf keberhasilan belajar secara klasikal. Selanjutnya, dari hasil postes siklus II diperoleh hasil belajar pendidikan kewarganegaraan siswa meningkat menjadi rata-rata 82,50 dengan persentase keberhasilan belajar secara klasikal yaitu $91,67 \%$ atau berati 22 orang siswa sudah meperoleh nilai tuntas dan dapat dikatakan berhasil karena telah mencapai $85 \%$ yang menjadi taraf keberhasilan belajar secara klasikal.

b. Aktivitas siswa selama proses pembelajaran terus mengalami peningkatan dari pertemuan pertama siklus I dengan rata-rata $56,56 \%$, meningkat menjadi $71,15 \%$ pada pertemuan kedua siklus I kemudian meningkat menjadi $81,67 \%$ pada pertemuan pertama siklus II serta meningkat hingga pertemuan kedua siklus II menjadi $84,90 \%$ dan tergolong baik.

c. Aktivitas peneliti selama proses pembelajaran sudah tergolong baik sekali atau aspek yang diamati berdasarkan format lembar observasi yang ada seluruhnya telah dilaksanakan.

\section{DAFTAR RUJUKAN}

Al-Tabany, Trianto Ibnu Badar. Abdullah, Sayid. 2015. Penerapan Model Pembelajaran Word SquareUntuk Meningkatkan Prestasi Belajar Siswa Kelas V
SDN Pengawu. Jurnal Kreatif Tadulako Online. 4:11.

Amri, Sofan. 2013. Pengembangan \& Model Pembelajaran Dalam Kurikulum 2013. Jakarta: Prestasi Pustakarya.

Aqib, dkk. 2011. Penelitian Tindakan Kelas. Bandung: Yrama Widya.

Aqib, Zainal. 2013. Model-Model, Media, dan Strategi pembelajaran Kontekstual (inovatif). Bandung: Yrama Widya.

Arikunto,Suharsimi.2010. Prodesur Penelitian Suatu Pendekatan Praktik. Jakarta: Asdi Mahasatya.

Dewi, $\quad$ Rosmala. 2015. Profesionalisasi Guru melalui Penelitian Tindakan Kelas. Medan: Unimed Press.

Daryanto. 2010. Belajar dan Mengajar. Bandung: Yrama Widya.

Fathurrohman, Muhammad. 2015. Model-Model Pembelajaran Inovatif. Jogjakarta: Ar-Ruzz Media.

Ibnu, Trianto. 2014. Mendesain Model Pembelajaran Inovatif, Progresif, dan Kontekstual. Jakarta: Prenadamedia.

Istarani. 2012. 58 Model Pembelajaran Inovatif. Medan: Media Persada.

Istarani dan Intan. 2015. Ensiklopedi Pendidikan Jilid I. Medan: Media Persada.

Jihad, A dan Abdul Haris. 2012. Evaluasi Pembelajaran. Yogyakarta: Multi Presindo. 
Kurniasih, Imas dan Berlin Sani. 2015. Ragam Pengembangan Model Pembelajaran Untuk Meningkatkan Profesionalitas Guru. Kata Pena.

Mulyasa, E 2013. Implementasi Kurikulum Tingkat Satuan Pendidikan Kemandirian Guru dan Kepala Sekolah. Jakarta: Bumi Aksara.

Mulyasa, E. 2013. Pengembangan dan Implementasi Kurikulum 2013. Bandung: Remaja Rosdakarya.

Ngalimun. 2014. Strategi dan Model Pembelajaran. Yogyakarta: Aswaja Pressindo.

Novianty, Fety. 2017. Penerapan Model Pembelajaran Word Squareuntuk Meningkatkan Hasil Belajar Siswa Pada Mata Pelajaran Pendidikan KewarganegaraanKelas Ix CSmp Negeri 1 Kecamatan Pemangkat Kabupaten Sambas. Jurnal Pendidikan Kewarganegaraan.1:2.

Purwanto. 2011. Evaluasi Hasil Belajar. Yogyakart: Pustaka Pelajar.

Ratnasari, Yesi. 2014. Penerapan Model Pembelajaran Word Square untuk Meningkatkan Aktivitas dan Hasil Belajar Siswa Kelas V Mata Pelajaran PKn Pokok Bahasan Keputusan Bersama di SDN Umbulrejo 01 Jember Tahun Pelajaran 2013/2014. Jurnal Ilmiah Pendidikan dan Pembelajaran. 1:1.
Sabri, Ahmad. 2010. Strategi Belajar Mengajar \& Micro Teaching. Jakarta: Ciputat Press.

Sani, Ridwan Abdullah. 2015. Inovasi Pembelajaran. Jakarta: Bumi Aksara.

Sanjaya, Wina. 2013. Strategi Pembelajaran Berorientasi Standar Proses Pendidikan. Jakarta: Kencana.

Simbolon, Naeklan dan Rizki Rahmatika. 2014. Meningkatkan Motivasi Belajar Siswa Dengan Menggunakan Model Pembelajaran Word Square Kelas IV SD Negeri 101868 Desa Sena Batang Kuis. Jurnal Pendidikan. 2:1.

Suprijono, Agus. 2010. Cooperative Learning Teori \& Aplikasi Paikem. Yogyakarta: Pustaka Pelajar.

Suryabrata, Sumadi. 2010. Psikologi Pendidikan. Jakarta: Raja Grafindo Persada.

Susanto, Ahmad. 2013. Teori Belajar Pembelajaran di sekolah Dasar. Jakarta: Kencana Prenada Media Group.

Swapranata, Ngurah Agung. 2016. Penerapan Model Pembelajaran Word Square Untuk Meningkatkan Hasil Belajar Ipa Siswa Kelas V Semester Genap. Jurnal Pendidikan dan Pembelajaran. 4:1.

Ula, S. Shoimatul. 2013. Revolusi Belajar. Yogyakarta: ArRuzz Media. 